\title{
CORPORATE GOVERNANCE DAN PENGUNGKAPAN MANAJEMEN RISIKO BANK SYARIAH DI INDONESIA
}

\author{
Annisa Difa Saufanny \\ Prodi Akuntansi Islam STEI Tazkia - Bogor \\ Siti Khomsatun \\ Institut Pesantren Mathali'ul Falah (IPMAFA) - Pati \\ Email: siti.khomsatun@gmail.com
}

\begin{abstract}
Based on Peraturan Bank Indonesia Nomor 13/23/PBI/2011, Indonesian Islamic bank has faced Rate of Return Risk and Equity Investment Risk that has been not faced by conventional bank. Moreover, Islamic bank also has had more reputation risk and compliance risk than conventional bank. The objective of this research is to provide empirical evidence of the influence of corporate governance on the risk management disclosure for Indonesian Islamic banking. Good Corporate Governance is proxied by total of Commissioners Board, total of Independent Commissioners Board, total of Audit Committee, total of Independent Audit Committee, and Sharia Supervisory Board. The method used in this research is multiple linear regression panel data. Using 35 unbalanced panel data from 11 Indonesia Islamic Bank for 2012 -2015, the result shows that only total audit committees that influence the risk management disclosures of Indonesian Islamic Bank.
\end{abstract}

Keywords: $\quad$ Indonesian Islamic Bank, Risk Management Disclosure, Good Corporate Governance

\section{PENDAHULUAN}

Peran bank sebagai lembaga yang memiliki dominan dalam suatu negara dapat mempengaruhi perkembangan perekonomian (Ali, 2006), sehingga harus ada peraturan dan pengawasan yang lebih ketat. Perbankan merupakan industri perantara keuangan yang mempuyai risiko tinggi. Oleh karenanya, diperlukan peningkatan efektivitas penerapan manajemen risiko dan good corporate governance sehingga bank mampu mengidentifikasi permasalahan lebih dini serta melakukan tindak lanjut yang sesuai dan lebih cepat (Bank Indonesia, 2011).

Industri perbankan syariah yang dimulai pada tahun 1992 dengan munculnya Bank Muamalat Indonesia (BMI) membuktikan mampu bertahan di masa krisis tahun 1997-1998. Namun, bukan berarti bank syariah terbebas dari risiko. Justru karena kehadiran bank syariah yang merupakan mandat dari masyarakat muslim akan menghadapi risiko tambahan berupa kepatuhan syariah dan reputasi karena membawa branding agama serta sistem bagi hasil yang dapat mempengaruhi fluktuasi keuangan perbankan syariah.

Peraturan Bank Indonesia Nomor 13/23/PBI/2011 pasal 5 menyebutkan terdapat 10 kelompok risiko pada perbankan syariah. Delapan 
risiko sama dengan profil risiko bank konvensional, yaitu: risiko kredit, risiko pasar, risiko likuiditas, risiko operasional, risiko hukum, risiko reputasi, risiko stratejik, risiko kepatuhan. Adapun dua risiko yang menjadi ciri khas perbankan syariah adalah risiko imbal hasil (Rate of Return Risk), dan risiko investasi (Equity Investment Risk).

Perbankan syariah yang menghadapi risiko lebih banyak dibandingkan bank konvensional perlu mendapatkan perhatian berbagai kalangan. Sebagaimana bank konvensional, perbankan syariah juga perlu mengelola risiko hingga melaporkan pelaksanaan manajemen risiko. Pelaporan manajemen risiko dapat dilakukan dengan mengungkapkan pengelolaan risiko dalam catatan laporan keuangan. Diharapkan dengan pengungkapan tersebut, pengguna akan lebih dapat ikut mengawasi dan mengatisipasi risiko yang dihadapi bank syariah.

Penelitian yang dilakukan Prayoga dan Almilia (2013) memaparkan bahwa informasi mengenai manajemen risiko sangat berguna bagi para pemangku kepentingan. Oleh karenanya, risiko harus diungkapkan secara tepat waktu untuk memenuhi kepentingan stakeholder (Amran et al., 2009) agar tidak salah dalam memperkirakan keadaan perusahaan di masa yang akan datang. Pengungkapan merupakan aspek penting yang dipertimbangkan oleh investor karena terdapat gambaran mengenai keadaan perusahaan dan kinerjanya di masa yang akan datang (Ali, 2006). Peraturan Bank Indonesia Nomor 14/14/PBI/2012 Tentang Transparansi dan Publikasi Laporan Bank menyatakan bahwa dalam rangka menciptakan disiplin pasar agar sejalan dengan perkembangan standar internasional diperlukan upaya peningkatan transparansi kondisi keuangan dan kinerja bank dengan mempublikasikan laporan untuk memudahkan penilaian oleh publik dan pelaku pasar.

Pedoman Umum Good Corporate Governance Indonesia yang diterbitkan oleh KNKG (Komite Nasional Kebijakan Governance) telah menyebutkan bahwa pengungkapan informasi manajemen risiko dalam sebuah perusahaan dianggap penting, karena dari pengungkapan risiko tersebut dapat dilakukan pengambilan keputusan untuk mengatasinya. Dalam pedoman ini juga disampaikan beberapa cara agar perusahaan mencapai kesinambungan yaitu dengan diterapkannya asas transparansi, akuntabilitas, responsibilitas, independensi serta kewajaran dan kesetaraan yang merupakan prinsip dasar dari peneranpan Good Corporate Governance.

Hussain \& Al-Ajmi (2012) mengemukakan bahwa peranan penting dalam manajemen risiko adalah dengan diterapkannya corporate governance di perbankan syariah. Pemangku kepentingan menggunakan corporate disclosure dalam proses pengambilan keputusan (Al- Haddad et al, 2011; Shehata, 2014). Bank yang sudah memiliki sistem informasi yang baik dapat dihadapkan pada sebuah risiko, apalagi jika tata kelola dalam perusahaannya tidak baik (Akmal, 2008). Todorovic (2013) mengatakan bahwa good corporate governance dapat membantu mencegah skandal perusahaan, fraud, dan potensi tanggung jawab perdata dan pidana perusahaan.

Penelitian di Indonesia yang membahas tentang pengungkapan manajemen risiko sudah banyak dilakukan (Fathimiyah et al, 2011; 
Suhardjanto et al, 2012; Prayoga dan Almilia, 2013; Harto dan Ruwita, 2013; Saidah, 2014). Penelitian-penelitian tersebut dilakukan pada perusahaan yang terdaftar di bursa efek indonesia dan perbankan konvensional. Penelitian pengungkapan manajemen risiko pada bank syariah, sejauh penelusuran baru dilakukan oleh Fitri (2014) yang meneliti peranan CG terhadap pengungkapan risiko finansial perbankan syariah. Penelitian Fitri (2014) belum mencakup semua jenis risiko sebagaimana yang dinyatakan oleh Peraturan Bank Indonesia Nomor 13/23/PBI/2011 pasal 5.

Perbankan syariah dihadapkan pada risiko yang lebih banyak dibandingkan perbankan konvensional. Untuk itu, perlu penelitian tentang pengungkapan manajemen risiko perbankan syariah di Indonesia dengan mengambil semua jenis risiko, tidak hanya keuangan saja. Hal ini dikuatkan karena bank syariah mempunyai risiko reputasi sebagai bank yang membawa nama syariah dan risiko akan kepatuhan terhadap syariah. Sehingga tujuan dari penelitian ini adalah menginvestigasi pengaruh $\mathrm{CG}$ terhadap pengungkapan perbankan syariah di Indonesia. Ukuran CG seperti jumlah dewan komisaris, dewan komisaris independen, jumlah komite audit, komite audit independen dan dewan pengawas syariah dapat membantu perusahaan dalam menerapkan pengungkapan manajemen risiko, sehingga ditengarai dapat mempengaruhi pengungkapan manajemen risiko perbankan syariah.

\section{TINJAUAN PUSTAKA DAN PENGEMBANGAN HIPOTESIS}

\subsection{TEORI KEAGENAN, CG DAN MANAJEMEN RISIKO}

Teori keagenan adalah kontrak yang melibatkan pemilik perusahaan (prinsipal) dan manajer (agen) (Jensen \& Meckling, 1976; Fama \& Jensen, 1983; Watt \& Zimmerman, 1986). Pemilik mempercayakan pengelolaan perusahaan kepada manajer (agen). Masalah keagenan muncul ketika masing-masing pihak berkeinginan memaksimalkan kepentingan masingmasing (Jensen \& Meckling, 1976).

Dalam kontrak keagenan, pemilik tidak mempunyai banyak akses ke pengelolaan perusahaan sehingga diperlukan laporan/informasi dari pengelola, yaitu berupa laporan keuangan. Ketika manajer tidak memberikan seluruh informasi yang diperlukan oleh pemilik, maka akan terjadi asimteri informasi antar keduanya (Jensen \& Meckling, 1976). Untuk memastikan bahwa manajer melaporkan informasi yang seharusnya diperlukan peran dari mekanisme corporate governance yang dapat melindungi hak-hak pemilik atas informasi yang seharusnya didapatkan.

Perbankan syariah merupakan industri yang dianggap memiliki nexus kontrak yang sama dengan teori keagenan. Teori keagenan pada perbankan tidak hanya terjadi antara pemilik dengan pengelola, melainkan juga mencakup antara nasabah (terutama nasabah berdasar akad syirkah) dan pengelola. Bank syariah juga sebenarnya mempunyai teori keagenan antara pengelola dan masyarakat terkait dengan operasional dan produk yang harus 
sejalan dengan syariah. Oleh karenanya, bank syariah diharapkan mampu memberikan transparansi yang memadai, berupa pengungkapan yang fair.

Menurut PBI Nomor 11/33/PBI/2009 Tentang Pelaksanaan GCG Bagi Bank Umum Syariah dan Unit Usaha Syariah bahwa perbankan syariah harus dikelola dengan menggunakan prinsip keterbukaan (transparency), akuntabilitas (accountability), pertanggungjawaban (responsibility), professional (professional), dan kewajaran (fairness), yang terangkum dalam definisi CG. Corporate governance memiliki peran penting dalam manajemen risiko, apabila corporate governance tidak diterapkan dengan baik akan menimbulkan krisis ekonomi, seperti munculnya beberapa risiko usaha termasuk dalam dunia perbankan (Rivai \& Ismal, 2013).

Informasi risiko perusahaan digunakan sebagai alat pengambilan keputusan yang cermat dan tepat, untuk itu perusahaan diharapkan mampu mengelola pengungkapkan informasi terkait risiko yang pada suatu perusahaan. Informasi yang diungkapkan tidak hanya informasi yang bersifat positif, melainkan informasi yang bersifat negatif yang terkait dengan aspek risiko manajemen. PBI Nomor 13/23/PBI/2011 telah mengatur bahwa yang harus diungkapkan perbankan syariah, yaitu: risiko kredit, risiko pasar, risiko likuiditas, risiko operasional, risiko hukum, risiko reputasi, risiko statejik, risiko kepatuhan, risiko imbal hasil dan risiko investasi. Disebutkan dalam PBI Nomor 13/23/PBI/2011 bahwa manajemen risiko adalah serangkaian metode dan prosedur yang digunakan untuk mengukur, mengidentifikasi, serta mengendalikan risiko yang timbul dari kegiatan usaha bank syariah.

\subsection{PENGEMBANGAN HIPOTESIS}

Dewan komisaris memiliki peran dalam sebuah perusahaan, yaitu mengawasi operasional yang berlangsung di dalam sebuah perusahaan. Pengawasan yang dilakukan dewan komisaris diharapkan dapat mengefektifkan salah satu cara untuk mengelola risiko, yaitu dengan dilakukan pengelolaan hingga pengungkapan risiko dalam sebuah laporan keuangan yang diterbitkan setiap tahunnya.

Sembiring (2005) mengatakan Semakin banyak jumlah anggota dewan komisaris yang ada dalam suatu perusahaan, maka akan semakin baik dalam melakukan pengungkapan informasi risiko perusahaan. Jumlah dewan komisaris yang besar akan memunculkan perpaduan kemampuan antara anggotanya sehingga akan meningkatkan ketelitian pengawasan dan pengendalian terhadap manajemen perusahaan (Suhardjanto dan Dewi, 2011). Dengan demikian jumlah dewan komisaris yang banyak diharapkan dapat meningkatkan kualitas pengungkapan informasi (Suhardjanto dan Dewi, 2011). Maka dapat dikembangkan hipotesis 1 :

H1: Jumlah Dewan Komisaris berpengaruh positif terhadap Pengungkapan Manajemen Risiko Perbankan Syariah

Pelaksanaan corporate governance akan berjalan dengan baik, apabila komisaris independen memahami dan melaksanakan tugasnya dengan baik dalam mengawasi, mengarahkan dan mengevaluasi pelaksanaan corporate 
governance dan kebijakan stragtegis bank (Suhardjanto dan Dewi, 2011). Semakin independen seorang dewan komisaris, maka pengawasan terhadap kegiatan operasional perusahan akan semakin baik. Dewan komisaris yang independen akan bertindak adil dalam melakukan pengawasan serta pelaporan kegiatan operasional manajemen. Dengan demikian, hipotesis dari penelitian ini adalah sebagai berikut:

H2: Independensi Dewan Komisaris Berpengaruh psitif terhadap Pengungkapan Manajemen Risiko Perbankan Syariah

Keberadaan komite audit perlu diperhatikan dalam hal pengelolaan perusahaan yang sehat (Chrisdianto, 2013). Komite audit memiliki fungsi utama untuk menjembatani shareholder, stakeholder, dan dewan komisaris dengan kegiatan pengendalian yang dilakukan oleh pihak manajemen, auditor internal, dan auditor eksternal (Utama, 2004). Komite audit memiliki peran dalam mewujudkan GCG di perusahaan, dengan melaksanakan tugasnya sesuai dengan prinsip-prinsip GCG itu sendiri. Prinsip-prinsip GCG yang meliputi kesetaraan, akuntabilitas, pertanggungjawaban, dan keterbukaan informasi (Chrisdianto, 2013). Sehingga dihipotesakan:

H3: Komite audit berpengaruh terhadap pengungkapan manajemen risiko perusahaan Perbankan Syariah

Peran komite audit dalam melakukan pemeriksaan terhadap laporan audit internal bertujuan untuk meninjau kemampuan anggota manajemen perusahaan dalam bertanggungjawab atas kesalahan atau kecurangan yang mendatangkan kerugian bagi pihak perusahaan (Chrisdianto, 2013). Sedangkan langkah yang dilakukan komite audit serta komite audit independen dalam keterbukaan informasi perusahaan, yaitu dengan melakukan pemeriksaan dan pengawasan terhadap upaya penyusunan laporan keuangan, agar laporan keuangan tersebut bisa menyajikan laporan keuangan serta informasi perusahaan yang dapat digunakan oleh stakeholder maupun shareholder (Chrisdianto, 2013).

Komite audit independen sama halnya dengan dewan komisaris independen. Di dalam perusahaan dirasa perlu memiliki dewan ataupun komite independen, tujuannya agar bisa mengawasi dan mengontrol perusahaan secara independen ataupun tidak dipengaruhi dan tidak berbenturan dengan kepentingan perusahaan. Dengan demikian, hipotesis dari penelitian ini adalah :

H4: Independensi Komite Audit Berpengaruh Psotif terhadap Pengungkapan Manajemen Risiko Perbankan Syariah

Dewan Pengawas Syariah (DPS) memiliki tugas yaitu memberikan saran dan nasihat kepada direksi serta mengawasi kegiatan perusahaan, agar sesuai dengan prinsip syariah (GGBS, 2011). Dengan adanya dewan pengawas syariah, bank lebih fokus untuk mengawasi kegiatan operasionalnya agar berjalan dengan prinsip syariah. Dalam kerangka profil risiko bank syariah terdapat risiko kepatuhan, yang mencakup tidak hanya 
patuh secara perundagnan dan peraturan di Indonesia melainkan juga hukumhukum Islam. Untuk mengawasi hal tersebut diperlukan DPS yang akan memberikan masukan, pengecekan dan pengawasan atas kepatuhan terhadap syariah. Sehingga dapat dikembangkan hipotesis sebagai berikut:

H5: Jumlah Dewan Pengawas Syariah berpengaruh terhadap Pengungkapan Manajemen Risiko Perbankan Syariah

\section{METODE PENELITIAN}

Populasi yang digunakan dalam penelitian ini adalah seluruh Bank Umum Syariah yang ada di Indonesia. Pemilihan sampel akan dilakukan dengan teknik purpose sampling, yaitu: Bank Umum Syariah itu memiliki data laporan keuangan yang terdapat informasi pengungkapan manajemen risiko perusahaan dan Good Corporate Governance selama tahun 2012 - 2015. Jenis sumber data pada penelitian ini adalah data sekunder, laporan keuangan dan laporan CGC bank syariah.

Variable dependen dalam penelitian ini adalah tingkat pengungkapan manajemen risiko perusahaan. Tingkat pengungkapan manajemen risiko diukur dengan menghitung item-item dari setiap risiko yang diungkapkan di dalam laporan tahunan setiap perbankan syariah. Setiap risiko memiliki beberapa item pengungkapan, apabila item tersebut ditemukan di dalam laporan tahunan berarti diberi nilai 1 , dan 0 untuk sebaliknya. Item-item pengungkapan risiko yang diungkapkan sesuai dengan Undang-undang yang berlaku di Indonesia PBI Nomor: 13/23/PBI/2011, yaitu: Risiko Kredit, Risiko Pasar, Risiko Likuiditas, Risiko Operasional, Risiko Hukum, Risiko Reputasi, Risiko Stratejik, Risiko Kepatuhan, Risiko Imbal Hasil (Rate of Return Risk), Risiko Investasi (Equity Investment Risk). Berikut pengukuran tingkat pengungkapan risiko:

Tingkat pengungkapan risiko $=\frac{\sum \text { Item pengu ngkapan risiko yang diungkapkan }}{\sum \text { Total item pengungkapan risiko }}$

Variable independen dalam penelitian ini organ-organ GCG perbankan syariah. GCG dalam penelitian ini diukur dengan Jumlah Dewan Komisaris, Dewan Komisaris Independen, Komite Audit, Komite audit Independen, serta Dewan pengawas syariah.

Penelitian ini menggunakan model regresi berganda dengan data panel. Berikut adalah model regresi yang digunakan dalam penelitian ini adalah sebagai berikut :

$$
\begin{gathered}
R M D_{i t}=\beta_{0}+\beta_{1} D K_{i t}+\beta_{2} D K I_{i t}+\beta_{3} K O M I T_{i t}+\beta_{4} K A I_{i t}+\beta_{5} D P S_{i t} \\
+\varepsilon_{i t}
\end{gathered}
$$

Keterangan:

$\mathrm{RMD}=$ Risk Management Disclosure (pengungkapan manajemen risiko)

DK = Jumlah Dewan Komisaris 
DKI $=$ Jumlah Dewan Komisaris Independen

KOMIT $=$ Jumlah Komite Audit

KAI = Jumlah Komite Audit Independen

DPS $=$ Jumlah Dewan Pengawas Syariah

$\varepsilon \quad=$ Error term

$\beta_{0} \quad=$ Konstanta

$\beta_{1}-\beta_{5} \quad=$ Koefisien Regresi

\section{PEMBAHASAN}

Bank umum syariah di Indonesia berjumlah 11 bank, berdasarkan data yang diperoleh tidak semua bank umum syariah menyajikan secara jelas pengungkapkan 10 risiko perusahaan yang sudah di tetapkan sesuai dengan PBI Nomor 13/23/PBI/2011. Sebanyak sembilan data bank umum syariah yang tidak memiliki kelengkapan data yang dapat menunjang penelitian ini. Jumlah seluruh laporan keuangan dalam penelitian ini selama 4 tahun adalah 44 data, dengan sembilan data yang tidak bisa digunakan, total data yang digunakan adalah 35 data (perbankan syariah-tahun). Daftar perusahaan yang diteliti selengkapnya dapat dilihat pada Tabel 1 menjelaskan jumlah bank umum syariah sesuai dengan kriteria yang sudah ditetapkan peneliti pada bab 3.

Tabel 1. Seleksi sampel

\begin{tabular}{|c|c|c|c|c|c|}
\hline No & \multicolumn{4}{|c|}{ Seleksi } & Jumlah Data \\
\hline 1 & \multicolumn{4}{|c|}{$\begin{array}{l}\text { Laporan keuangan yang memiliki laporan tahunan dan } \\
\text { laporan GCG (perbankan syariah-tahun) }\end{array}$} & 44 \\
\hline 2 & \multicolumn{4}{|c|}{$\begin{array}{l}\text { Laporan keuangan yang tidak mempublikasikan } \\
\text { laporan keuangan (perbankan syariah-tahun) }\end{array}$} & (9) \\
\hline 3 & \multicolumn{4}{|c|}{ Sampel Akhir (perbankan syariah-tahun) } & 35 \\
\hline \multicolumn{6}{|c|}{ Sumber : Data diolah, 2016} \\
\hline \multirow{2}{*}{\multicolumn{6}{|c|}{$\begin{array}{l}\text { Statistik deskriptif dari masing-masing penelitian ini dapat dilihat melalui } \\
\text { Tabel 2: } \\
\text { Tabel 2. Statistik Deskriptif }\end{array}$}} \\
\hline & & & & & \\
\hline & Mean & Median & $\underset{\mathrm{m}}{\text { Minimu }}$ & $\begin{array}{l}\text { Maximu } \\
\mathrm{m}\end{array}$ & $\begin{array}{l}\text { Stand. } \\
\text { Deviasi }\end{array}$ \\
\hline & $\begin{array}{r}0.63428 \\
6 \\
\end{array}$ & 0.625 & 0.275 & 0.95 & 0.165285594 \\
\hline & DK & 3 & 3 & 6 & 1.10992467 \\
\hline & 0.72 & 0.67 & 0.50 & 1.00 & 0.170403487 \\
\hline
\end{tabular}




\begin{tabular}{crrrrr}
\hline KOMIT & 4 & 3 & 2 & 6 & 1.008368347 \\
\hline KAI & 0.70 & 0.67 & 0.2 & 1 & 0.296475562 \\
\hline DPS & 2 & 2 & 2 & 3 & 0.497050122 \\
\hline
\end{tabular}

Keterangan:

$R M D=$ Jumlah Pengungkapan manajemen risiko yang dilakukan; $D K=$ Jumlah dewan komisaris di perbankan syariah; DKI= Jumlah dewan komisaris independen dibagi jumlah dewan komisaris; KOMIT = Jumlah komite audit di perbankan syariah;

$K A I=$ Jumlah komite audit independen dibagi dengan jumlah komite audit; $D P S=$ Jumlah dewan pengawas syariah di perbankan syariah

Sumber: data diolah (Output STATA)

Tabel 2 menunjukkan nilai rata-rata pengungkapan risiko manajemen di perbankan syariah di Indonesia berada pada score 0,63\%, hal ini menunjukkan bahwa pengungkapan risiko yang dilakukan bank syariah belum sepenuhnya dipatuhi. Sebanyak lima bank yang memiliki rata-rata pengungkapan risiko di atas 50\%, yaitu bank Mega, Panin, Muamalat, BCA, dan BSM. Terdapat beberapa bank yang tidak mengungkapkan 10 risiko secara jelas sesuai dengan PBI Nomor 13/23/PBI/2011, terutama dua risiko yang membedakan dengan bank konvensional, yaitu risiko imbal hasil dan risiko investasi. Nilai rata-rata pengungkapan risiko imbal hasil dan investasi berturut-turut sebesar $42,04 \%$ dan $46,59 \%$. Hal ini menunjukkan bahwa sedikit perbankan syariah yang sudah mengungkapakan risiko imbal hasil dan investasi secara jelas.

Peraturan Otoritas Jasa Keuangan No.33 yang menyebutkan jumlah dewan komisaris (DK) bagi setiap emiten dan perusahaan publik paling sedikit 2 orang. Tabel 2 menunjukkan nilai rata-rata jumlah dewan komisaris sebesar 4, nilai terkecil sebesar 3 dan nilai terbesarnya 6. Nilai standar deviasi lebih kecil dibandingkan dengan rata-rata menandakan bahwa jumlah dewan komisaris yang tidak banyak perbedaan setiap tahunnya. Pada table 2 menunjukkan rata-rata dewan komisaris independen sebesar $72 \%$, nilai terkecil sebesar $50 \%$ dan nilai terbesar $100 \%$.

Jumlah Komite audit (KOMIT) pada Tabel 2 menunjukkan rata-rata sebesar 4. Nilai terkecil dari jumlah komite audit sebesar 2 dan nilai terbesar 6. Jumlah komite audit pada Pedoman GCG yang dibuat oleh KNKG menyebutkan minimal berjumlah 3 orang setiap perbankan syariah. Dengan demikian perbankan syariah sudah banyak yang memenuhi jumlah komite audit yang sudah ditetapkan dalam pedoman. Table 2 menunjukkan nilai ratarata komite audit independen (KAI) sebesar $70 \%$ perbankan syariah di Indonesia rata-rata sudah memiliki komite audit independen yang ahli dibidang akuntansi dan keuangan yang tidak memiliki hubungan keluarga dengan dewan komisaris, dewan direksi, dan pemegang saham.

Jumlah Dewan pengawas syariah (DPS) memiliki jumlah yang sama di setiap tahunnya, dilihat dari nilai rata-rata lebih besar dari nilai standar deviasinya. Nilai rata-rata jumlah DPS di perbankan syariah selama 4 tahun sebesar 2 dengan nilai terkecil jumlah DPS 2 dan nilai terbesarnya adalah 3 . 


\subsection{PENGUJIAN HIPOTESIS}

Pengujian hipotesis ini menggunakan hasil dari uji robust, dikarenakan sebelumnya pada uji asumsi klasik terkena autokolerasi. Tabel 3 berikut merupakan hasil pengolahan data untuk pengujian hipotesis:

Tabel 3. Pengujian Hipotesis

\begin{tabular}{|c|c|c|c|c|c|}
\hline Variabel & Coefficient & Sig-t & Sig-F & Hipotesis & Adj-R \\
\hline DK & 0,0060673 & 0,859 & \multirow{5}{*}{0,0109} & Tidak terbukti & \multirow{5}{*}{0,1686} \\
\hline DKI & $-0,169619$ & 0,401 & & Tidak terbukti & \\
\hline KOMIT & 0,0628466 & 0,013 & & Terbukti & \\
\hline KAI & 0,0508005 & 0,697 & & Tidak terbukti & \\
\hline DPS & $-0,0503508$ & 0,470 & & Tidak terbukti & \\
\hline
\end{tabular}

Hasil uji F, menunjukkan nilai F-stat sebesar 0,0109. Hasil perhitungan stata menunjukkan nilai F-stat lebih kecil dari F-tabel sebesar 0,05 , maka tolak 0 dan terima 1 yang berarti model ini secara simultan semua variable independen (dewan komisaris, dewan komisaris indepeden, rapat dewan komisaris, komite audit, komite audit independen, dan dewan pengawas syariah) secara bersama-sama berpengaruh secara signifikan terhadap variabel dependen, pengungkapan manajemen risiko.

Gambar 3 menunjukkan besarnya nilai Adjusted R-squared penelitian ini sebesar 16,86\%. Dengan demikian, berarti variabel independen (DK, DKI, RDK, KOMIT, KAI, dan DPS) mempengaruhi variabel dependen (RMD) sebesar $16,86 \%$. Sementara $83,14 \%$ dipengaruhi oleh variabel independen lain diluar variabel dalam penelitian ini.

Pada Tabel 3 menunjukkan bahwa variabel dewan komisaris (DK) memiliki nilai signifikansi sebesar 0,858 atau yang lebih besar dari nilai signifikansi 0,05. Hasil pengujian menunjukkan DK tidak berpengaruh positif signifikan terhadap pengungkapan risiko perbank syariah. Hasil ini berbeda dengan prediksi. Hasil penelitian ini bertentangan dengan hasil penelitian Saidah (2014), Suhardjanto et al, (2012), dan Suhardjanto \& Dewi (2011) yang menyatakan bahwa dewan komisaris memiliki pengaruh terhadap pengungkapan risiko. Hasil penelitian ini serupa dengan hasil penelitian yang dilakukan oleh Fitri (2014). Hasil penelitian yang dilakukan oleh Joeswanto \& Malelak (2015) juga menunjukkan tidak adanya pengaruh dewan komisaris terhadap variabel manajemen risiko bank. Joeswanto \& Malelak (2015) menyebutkan fenomena yang terjadi dalam industri perbankan, salah satunya adalah dewan komisaris dilarang terlibat dalam pengambilan keputusan kegiatan operasional bank. Dewan Komisaris tidak boleh turut serta dalam mengambil keputusan operasional, sehingga tidak memiliki wewenang dalam penyusunan laporan keuangan. Di dalam laporan keuangan tersebut informasi risiko perusahaan disajikan, sehingga ini merupakan salah satu alasan variabel dewan komisaris tidak berpengaruh. 
Jumlah dewan komisaris independen (DKI) memiliki nilai signifikansi 0,401 yang lebih besar dari 0,05, sehingga DKI tidak berpengaruh terhadap pengungkapan manajemen risiko. Hal ini serupa dengan hasil penelitian Suhardjanto et al, (2012), menyatakan bahwa dewan komisaris independen tidak berpengaruh terhadap pengungkapan risiko di perbankan. Hasil tidak signifikannya DKI mempengaruhi pengungkapan managemen risiko yaitu: bank umum syariah di Indonesia cenderung mematuhi regulasi yang telah dibuat oleh GGBS (Good Governance Bank Syariah) tanpa melihat integritas dari dewan komisaris independen itu sendiri.

Berdasarkan hasil uji hipotesis menunjukkan bahwa nilai signifikansi 0,013 yang lebih kecil dari nilai signifikansi 0,05 dengan koefisien bertanda positif. Hasil ini menunjukkan bahwa ukuran komite audit berpengaruh positif terhadap pengungkapan risiko di perbankan syariah. Adanya pengaruh antara ukuran komite audit terhadap pengungkapan risiko perbankan syariah dikarenakan komite audit adalah komite yang dibentuk untuk membantu memaksimalkan fungsi pengawasan perusahan, pengawasan disini dilakukan dengan membuat serta melaporkan kegiatan operasional bank dan informasi risiko perbankan dalam bentuk laporan keuangan. Komite audit bertugas mengawasi aktifitas, pembuatan serta pengaudit an laporan keuangan. Dimana laporan keuangan disusun oleh seorang akuntan dan di audit oleh seorang auditor yang berasal dari dalam maupun luar perusahaan.

Selain itu, Pedoman GGBS (2011) menyebutkan tugas komite audit ialah memastikan bahwa laporan keuangan yang disajikan wajar sesuai dengan prinsip akuntansi, dan kepatuhan kepada prinsip-prinsip syariah agar terhindar dari risiko kepatuhan perbankan syariah. Hasil penelitian ini sesuai dengan hasil penelitian yang dilakukan oleh Saidah (2014) dan bertentangan dengan penelitian yang dilakukan oleh Fitri (2014). Bahwa semakin besar ukuran komite audit maka pengawasan serta pengendalian internal perbankan syariah akan semakin efektif. Sehingga dapat meminimalisasi konflik keagenan yang terjadi akibat keinginan manajemen untuk meningkatkan kesejahteraan diri sendiri, dengan memanipulasi informasi risiko perusahaan.

Salah satu komponen yang merupakan prinsip dalam GCG adalah transparansi. Dimana transparansi disini meliputi pengungkapan informasi perusahaan, oleh karena itu dewan komisaris membetuk komite-komite untuk membantu tugasnya dalam membuat pengungkapan informasi perusahaan secara akurat dan tepat waktu. Salah satu komite tersebut adalah komite audit, komite audit berperan dalam pengendalian internal perusahaan, dengan mengawasi, mengaudit dan menyajikan informasi perusahaan sesuai dengan standar yang berkualitas tinggi dan informasinya dapat dipercaya pada tingkat manajemen dan perusahaan (Utama, 2004).

Hasil statistik komite audit independen menunjukkan nilai signifikansi 0,697 yang lebih besar dari 0,05. Hasil ini menunjukkan bahwa independensi komite audit tidak berpengaruh positif terhadap pengungkapan risiko di perbankan syariah. Sebagaimana yang sudah ditetapkan dalam aturan yang dibuat oleh BAPEPAM, emiten diharapkan memiliki komite audit independen yang diangkat dari luar perusahaan atau dewan komisaris 
independen perusahaan. Hal ini juga selaras dengan peraturan GCG untuk perbankan syariah. Dengan dibuatnya peraturan untuk memiliki komit audit independen, bank umum syariah cenderung untuk mematuhi peraturan tanpa memperhatikan integritas komite audit independen. Hal ini membuat kinerja komite audit menjadi tidak efektif. Berapapun jumlah komite audit independen yang dimiliki perbankan syariah tidak berpengaruh terhadap pengungkapan risiko.

Hal ini serupa dengan penelitian Suhardjanto (2011), Wardhana \& Cahyonowati (2013), Suhardjanto et al, (2012), bahwa ukuran komite audit independen tidak memiliki pengaruh terhadap pengungkapan risiko perusahaan. Hal ini terjadi karena beberapa faktor yaitu, pemilihan komite audit independen yang kurang mempertimbangkan integritas serta kompetisi dalam pemilihan komisaris independen dapat menyebabkan kurangnya pemahaman komite audit independen dalam menjalankan tugasnya. Selain itu Wardhana \& Cahyonowati (2013) menyebutkan bahwa penentuan proporsi komite audit independen yang belum memenuhi persyaratan BAPEPAM, dilakukan bukan untuk memaksimalkan kinerja perbankan syariah.

Pada tabel 3 menunjukkan bahwa variabel dewan pengawas syariah (DPS) memiliki nilai signifikansi 0,470 yang lebih besar dari 0,05. Hasil penelitian ini menunjukkan bahwa dewan pengawas syariah tidak berpengaruh terhadap pengungkapan risiko di perbankan syariah. Hal ini dikarenakan kegiatan dewan pengawas syariah yang meliputi persetujuan produk baru, mengawasi kegiatan operasional agar sesuai dengan akad syariah dan membuat pernyataan bahwa bank tersebut sudah menjalankan kegiatan operasionalnya sesuai dengan prinsip syariah. DPS tetap mengawasi agar akad serta kegiatan operasionalnya agar sesuai dengan syariah.

Dewan pengawas syariah (DPS) melaksanakan tugasnya dalam mengawasi kegiatan operasional perbankan syariah agar sesuai dengan prinsip syariah. Tugas DPS yaitu memberikan saran dan nasihat kepada direksi serta mengawasi perusahaan agar kegiatan operasionalnya sesuai dengan prinsip syariah (GGBS, 2011). Kegiatan operasional yang dilakukan perbankan syariah harus memenuhi prinsip syariah. Pemenuhan prinsip syariah sebagaimana disebutkan dalam Peraturan Bank Indonesia Nomor 10/16/PBI/2008, yaitu dengan memenuhi ketentuan pokok hukum Islam antara lain prinsip keadilan dan keseimbangan, kemaslahatan, dan universalisme (alamiyah) serta tidak mengandung unsur gharar, maysir, riba, zalim, dan objek haram. Hal ini menyebabkan peneliti menduga bahwa dewan pengawas syariah dapat berpengaruh terhadap pengungkapan risiko pada perbankan syariah.

Hasil penelitian ini sama dengan hasil penelitian Khoirudin (2013). Penelitian yang dilakukan oleh Khoirudin (2013) dengan sampel penelitian seluruh bank syariah di Indonesia pada tahun 2010-2011, dengan variabel terikatnya adalah Islamic Social Reporting. Tidak adanya pengaruh variabel dewan pengawas syariah pada penelitian yang dilakukan oleh Khoirudin (2013), dikarenakan dewan pengawas syariah masih berfokus pada tugasnya 
dalam kegiatan operasional bank, sehingga tingkat pengungkapan ISR berkurang.

\section{SIMPULAN}

Penelitian ini bertujuan untuk mengetahui pengaruh Good Corporate Governance yang diukur dengan variabel Jumlah Dewan Komisaris, Ukuran Dewan Komisaris Independen, Jumlah Rapat Dewan Komisaris, Jumlah Komite Audit, Ukuran Komite Audit Independen, dan Dewan Pegawas Syariah terhadap pengungkapan risiko di Bank Umum Syariah. Penelitian ini menggunakan data sekunder yang diperoleh dari laporan tahunan bank dan laporan Good Corporate Governance Bank Umum Syariah tahu 2012-2015.

Hasil penelitian menunjukkan bahwa variabel CG yang berpengaruh terhadap pengungkapan manajemen risiko perbankan syariah hanya besaran komite audit. Sedangkan Jumlah Dewan Komisaris, Ukuran Dewan Komisaris Independen, Jumlah Rapat Dewan Komisaris, Ukuran Komite Audit Independen, dan Dewan Pegawas Syariah tidak mempengaruhi pengungkapan manajemen risiko perbankan syariah. Jumlah komite audit berpengaruh positif terhadap pengungkapan risiko di perbankan syariah. Adanya pengaruh antara ukuran komite audit terhadap pengungkapan risiko perbankan syariah dikarenakan komite audit adalah komite yang dibentuk untuk membantu memaksimalkan fungsi pengawasan perusahan, pengawasan disini dilakukan dengan membuat serta melaporkan kegiatan operasional bank dalam bentuk laporan keuangan.

Penelitian ini mempunyai keterbatasan yaitu hanya menggunakan enam variabel independen. Sehingga penelitian selanjutnya dapat mengeksplorasi variabel GCG yang mempengaruhi pengungkapan manajemen risiko seperti eksplorasi peran dari komite audit yang memang bertugas langsung dalam pengawasah penyediaan informasi. Penelitian ini juga belum mencoba mencari lebih lanjut item risiko apa yang dipengaruhi oleh variabel independen. Penelitian selanjutnya diharapkan dapat menginvestigasi per item risiko dan dapat menggunakan faktor analisis.

\section{DAFTAR PUSTAKA}

Akmal, H. (2008). Good Corporate Governance dan Manajemen Risiko di Bank Syari'ah. Thesis. UIN Sunan Kalijaga.

Ali, M. (2006). Manajemen Risiko. In Strategi Perbankan dan Dunia Usaha Menghadapi Tantangan Globalisasi Bisnis (p. 312). PT Raja Grafindo Persada. 
Almilia, E. B. (2013). Pengaruh Struktur Kepemilikan dan Ukuran Perusahaan Terhadap Pengungkapan Manajemen Risiko. JURNAL Akuntansi \& Keuangan .

Amran, A., Manaf Rosli Bin, A., \& Che Haat Mohd Hassan, B. (2008). Risk reporting: An exploratory study on risk management disclosure in Malaysian annual reports. Managerial Auditing Journal, 24(1), 39-57.

Antonio, M. S. (2001). Bank Syariah Dari Teori ke Praktek. Gema Insani.

Bank Indonesia. (2006). Peraturan Bank Indonesia Nomor 8/14/PBI/2006 Tentang Pelaksanaan Good Corporate Governance Bagi Bank Umum. Bank Indonesia. Jakarta

Bank Indonesia. Peraturan Bank Indonesia Nomor 11/33/PBI/2009 Tentang Pelaksanaan Good Corporate Governance bagi Bank Umum Syariah dan Unit Usaha Syariah. Bank Indonesia. Jakarta

Bank Indonesia. (2011). Peraturan Bank Indonesia Nomor 13/23/PBI/2011 Tentang Penerapan Manajemen Risiko Bank Umum Syariah dan Unit Usaha Syariah. Bank Indonesia. Jakarta.

Bank Indonesia. (2012). Peraturan Bank Indonesia Nomor 14/14/PBI/2012 Tentang Transparansi dan Publikasi Laporan Bank. Bank Indonesia. Jakarta.

Chrisdianto, B. (2013). Peran Komite Audit Dalam Good Corporate Governance. Jurnal. Universitas Surabaya. Surabaya.

Departemen Agama RI, Al-Qur'an dan Terjemahannya, Bandung : Dipenogoro, 2000

Departemen Keuangan Republik Indonesia. (1996). Keputusan Ketua Badan Pengawas Pasar Modal dan Lembaga Keuangan Nomor : KEP38/PM/1996 Tentang Kewajiban Penyampaian Laporan Tahunan Bagi Emiten atau Perusahaan Publik. Departemen Keuangan Republik Indonesia.

Departemen Keuangan Republik Indonesia. (2004). Keputusan Ketua Badan Pengawas Pasar Modal dan Lembaga Keuangan Nomor : KEP29/PM/2004 Tentang Pembentukan dan Pedoman Pelaksanaan Kerja Komite Audit. Departemen Keuangan Republik Indonesia.

Departemen Keuangan Republik Indonesia. (2006). Keputusan Ketua Badan Pengawas Pasar Modal dan Lembaga Keuangan Nomor : KEP134/BL/2006 Tentang Kewajiban Penyampaian Laporan Tahunan Bagi Emiten atau Perusahaan Publik. Departemen Keuangan Republik Indonesia.

Fathimiyah, V., Rudi Zulfikar dan Fara Fitriyani. (2012). Pengaruh Struktur Kepemilikan Terhadap Risk Management Disclosure (Studi Survei 
Industri Perbankan yang Listing di BEI tahun 2008-2009). Simposium Nasional Akuntansi. Banjarmasin.

Fitri. E. R. (2014). Pengaruh Corporate Governance Terhadap Pengungkapan Risiko Finansial pada Bank Umum Syariah di Indonesia. Skripsi. UIN Sunan Kalijaga Yogyakarta.

Ghozali, Imam. (2006). 200 Analisis Multivariate Dengan Program SPSS. Badan Penerbit Undip. Semarang.

Gujarati, D. (2006). Dasar-Dasar Ekonometrika. Jakarta : Erlangga.

Harto, P., \& Ruwita, C. (2013). Analisis Pengaruh Karakteristik Perusahaan dan Corporate Governance Terhadap Pengungkapan Risiko Perusahaan. Diponegoro Journal Of Accounting.

Abu Hussain, H., \& Al-Ajmi, J. (2012). Risk management practices of conventional and Islamic banks in Bahrain. The Journal of Risk Finance, 13(3), 215-239.

Jensen, M. C., \& Meckling, W. H. (1976). Theory of the firm: Managerial behavior, agency costs and ownership structure. Journal of financial economics, 3(4), 305-360.

Khoirudin, Amirul. (2011). Pengaruh Elemen Good Corporate Governance terhadap Pengungkapan Islamic Social Reporting pada Perbankan Syariah. Skripsi. Universitas Negri Semarang.

KNKG. (2006). Pedoman Umum Corporate Governance Indonesia. Komite Naional Kebijakan Governance.

KNKG. (2011). Good Governance Bisnis Syariah. Komite Nasional Kebijakan Governance.

OECD. (2004). OECD Principle Of Corporate Governance. Organistion For Corporation and Development.

Prayoga, E. B., \& Almilia, L. S. (2013). Pengaruh Struktur Kepemilikan Dan Ukuran Perusahaan Terhadap Pengungkapan Manajemen Risiko. Jurnal Akuntansi dan Keuangan, 4(1).

Rivai, V., \& Ismal, R. (2013). Islamic Risk Management For Islamic Bank. PT Gramedia Pustaka Utama.

Ruwita, C. dan Harto, Puji. (2013). Analisis Pengaruh Karakteristik Perusahaan dan Corporate Governance Terhadap Pengungkapan Risiko Perusahaan. Diponegoro Journal Of Accounting.

Saidah, Siti. (2014). Pengaruh Mekanisme Corporate Governance Terhadap Pengungkapan Risiko Perusahaan : Studi Empiris Laporan Tahunan Perusahaan Non Keuangan yang Terdaftar di Bursa Efek Indonesia Periode 2011-2013. Jurnal Akuntansi UNESA. 
Sembiring, Eddy Rismanda. (2005). Karakteristik Perusahaan dan Pengungkapan Tanggung Jawab Sosial : Studi Empiris pada Perusahaan di Bursa Efek Jakarta. Simposium Nasional Akuntansi.

Shehata, N. (2014). Theories and Determinants of Voluntary Disclosure. Accounting and Finance Research.

Suhardjanto, D., \& Dewi, A. (2011). Pengungkapan Risiko Finansial dan Tata Kelola Perusahaan: Studi Empiris Perbankan Indonesia. Jurnal Keuangan dan Perbankan, 15(1), 105-118.

Suhardjanto, D., Dewi, A., Rahmawati, E., \& Firazonia, M. (2012). Peran Corporate Governance dalam Praktik Risk Disclosure pada Perbankan Indonesia. JOURNAL OF ACCOUNTING AND AUDITING, 9(1), 1630 .

Supriyono, Edy., Achmad Abdul Mustaqim, dan Djoko Suhardjanto. (2014). Pengaruh Corporate Governance Terhadap Tingkat Kepatuhan Mandatory Disclosure Konvergensi IFRS di Indonesia. Universitas Mataram.

Todorovic, I. (2013). Impact of corporate governance on performance of companies. Montenegrin Journal of Economics, 9(2), 47.

Utama, M. (2004). Komite Audit, Good Corporate Governance dan Pengungkapan Informasi. Jurnal Akuntansi dan Keuangan Indonesia, 1(1), 61-79. 
